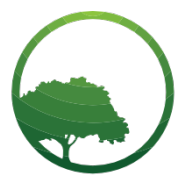

Research in Business \& Social Science

IJRBS VOL 8 NO 5 ISSN: 2147-4478

\title{
Influence of bank stability on the financial performance of commercial banks in South Sudan
}

\author{
Bak Barnaba Chol ${ }^{*}$, Elizabeth Kalunda Nthambi ${ }^{b}$, Joseph N. Kamau ${ }^{c}$ \\ ${ }^{a, b, c}$ Chandaria School of Business, United States International University - Africa, Nairobi, Kenya
}

Crossref

\begin{tabular}{l} 
A R T I C L E IN F O \\
\hline Article history: \\
Received 29 July 19 \\
Received in revs. form 15 August 19 \\
Accepted 18 August 19 \\
\hline Keywords: \\
Bank stability \\
Asset quality \\
Management efficiency \\
Liquidity \\
Financial performance \\
JEL Classification: \\
F31 \\
O10
\end{tabular}

\begin{abstract}
A B S T R A C T
Despite increasing bank competitiveness within the country for the past half-decade there has been scant literature examining their stability in the face of the numerous internal factors and economic shocks. Hence the current research aims to determine if bank stability has any effect on commercial bank's fiscal performance in South Sudan. The study was guided by the CAMEL model metrics (ROA and ROE) in measuring stability and its influence on the monetary performance of commercial banks. SPSS 23 was used to carry out subsequent descriptive and inferential statistical analysis. The study was primarily grounded on the CAMEL model. The correlation tests indicated that asset quality had a strong positive effect on monetary performance of commercial banks $p=.784$; a strong positive effect of management efficiency $p=.758$ and liquidity $p=.620$.
\end{abstract}

\section{Introduction}

The financial system is a nerve center of economic development, the financial system is key in provision of key monetary intermediation with the aim of balancing the flow of money within the economy by making it able for individuals with surplus amounts to save and those without to access these excess funds for consumption and investment in business ventures (Athanasoglou, Brissimis, \& Delis, 2008). The commercial bank in all countries is important in financial development of the economy. The last 20 years has witnessed tremendous structural changes in terms of operations, structures and the general performance of the commercial banking industry (Ongore \& Kusa, 2013).

Commercial banks have the goal of registering better performance through sustained profitability and growth (Pearce \& Robinson, 2011). However, attempts to realize such successes, are often affected by multiple operating market conditions such as the level of competition, stakeholders management, political landscape, business legal regime, the cost of doing business, new innovative products, internal organizational structure, emerging technologies, and effects of globalization (Kotler \& Armstrong, 2013).

According to Hilscher and Raviv, (2014) bank stability fosters market discipline within the economy of a country which is key in enhancing the foreign investor confidence level which is essential in enhancing investments and spur economic growth. In another review of transition economies, (Fang, Hasan, \& Marton, 2014); indicate that the stability of banks has spurred institutional development which are integral to economic growth. Lamers, Mergaerts, Meuleman, and Vander Vennet, (2016) examined the tradeoff between bank stability and monetary policy and concluded that bank stability helps reduce systemic risk within banks which helps in operationalization of accommodative monetary policies.

\footnotetext{
* Corresponding author. Tel: +254722832987 ORCID ID: 0000-0002-1093-8428
}

Peer review under responsibility of Bussecon International Academy.

(C) 2019 Bussecon International. Hosting by SSBFNET- Center for Strategic Studies in Business \& Finance. All rights reserved.

https://doi.org/10.20525/ijrbs.v8i5.467 
There are several indicators that can be applied when measuring bank stability. Among these measures as proposed by the BASELS Acord is the CAMEL framework (Beck et al., 2009). The banking stability index which was established by Ghosh (2010) is another measure of bank stability. It involves using the main aspects of banking operations then carrying out examinations on the factors which have the most influence on the index.

Financial performance in banking industry has been of interest to academic research and to stakeholders in the banking industry. This is due to the fact that financial performance has a critical implication for economic growth in any country and its generally considered to be the reflector of financial and economic conditions of a country other than its intermediation role in an economy (Gatuhi, 2015; Ongore \& Kusa, 2013). Financial performance is also important due to competitiveness in the world economy not only to stakeholders of a firm but also to firms within the same industry (Yalcin, Bayrakdaroglu, \& Kahraman, 2012). The study measured financial performance using ROA and ROE.

The Central Bank of South Sudan (2016) reports that there exist 29 registered commercial banks operating in the country, 11 national banks 11 joint ventures, and 7 foreign-owned banks. The central bank also regulates 8 micro finance institutions and 84 forex bureaus. Statistics from the Bank of South Sudan on the financial soundness indicators for the Banking sector in the country as contained in the IMF (2017) reports indicates that Asset quality measure in terms of non-performing loans against total loans rose from $18.7 \%$ in March 2014 to a high of $54.9 \%$ in September 2016. Liquidity expressed in terms of liquid assets to total assets decreased from $78.7 \%$ in March 2014 to a low of $46.7 \%$ in September 2016. Overall the statistics portray a negative image of the banking sector performance in South Sudan.

Despite emerging evidence that stable banking institutions are essential to promoting institutional performance and economic growth; the IMF (2017) report indicates that commercial banks in South Sudan are faced by a myriad of internal challenges as well as macroeconomic constraints that have limited the development within the sector resulting in the conclusion that the banks are failing as indicated by the financial soundness indicators utilized by the Central Bank of South Sudan. According to Bank of South Sudan, (2013) report on the South Sudan Financial sector the shift from Islamic to Conventional Banking after the independence of South Sudan in 2011 led to imbalances in the structuring of a new financial system. Garang (2014) also indicates that there has been limited growth in the South Sudan banking sector; further he stated lack of financial inclusivity and institutional structuring to be the cause of limited development and performance of the sector.

Available literature (Ongore \& Kusa, 2013; Chechet \& Olayiwola, 2014; Naceur \& Omran, 2010); have indicated that there are both firm-specific and marekt specific factors which affect commercial bank rate of return. Despite all these efforts exerted to determine factors affecting performance of Sudanese banks, none of the studies captured the influence of bank stability on commercial banks financial performance utilizing CAMEL model and moderating ownership especially in the context of South Sudan. Furthermore there is need to evaluate the effectiveness of the CAMEL model with the growing adoption of other metrics such as ROA, ROE or EAGLES model within the banking sector. The purpose of the study was to examine the influence of bank stability on the financial performance of commercial banks in South Sudan.

\section{Literature Review}

\section{CAMEL Model}

Developed in 1979 by US Federal regulators, the CAMEL model aids in the process of examining bank performance. CAMEL is a ratio-based model commonly used for the evaluation of performance and ranking. By using the CAMEL rating system, US supervisory authorities became the first to carry out on-site examinations of banking institutions back in the 80s (Hansda, 1995). This led to the introduction of a uniform rating system for all banks across the states. CAMEL stands for the following components; capital adequacy, asset quality, management efficiency, earning quality, and liquidity.

Even though there are many aspects of performance measurements of commercial banks that can be analysed, the CAMEL framework remains to be the most accepted measure of financial performances of commercial banks since it possesses certain advantages. The model is advantageous due to its ability in early signalling of potential danger, further the CAMEL has the ability to improve their overall performance of banks by creating a sense of competition among each other (Bodla \& Verma, 2008).

\section{Bank Stability and Financial Performance}

Kadioglu, Telceken, and Ocal, (2017) undertook a study to determine how Asset Quality affects profitability among banks. The main aim of this study was to determine the effect of nonperforming loans on profitability of Turkish financial institutions. Panel regression method was applied to the quarterly data of 55 Turkish Banks between the 1st quarter of 2005 and the 3rd quarter of 2016. The results indicated that there is a significant negative relationship between nonperforming loans and bank profitability. Banks with high levels of nonperforming loans were found to have lower asset quality.

Ghosh (2017) studied how reforms initiated as part of corporate governance affect the performance of banks operating in the Middle East and North Africa. Data for the period between 2000-2012 was utilized in the study. Further, fixed effects regression within a difference-in-differences specification was adopted in data analysis. The researcher reported that it was not all aspects of governance 
that are integral in enhancing bank effectiveness. It was thus the researcher's conclusion that managerial components; operational efficiency and the access to capital were the main factors that influenced bank performance.

Ndoka, Islami, and Shima, (2017) examined how liquidity risk management affects performance of Albanian Commercial Banks. Carrying out panel data regression in analysis of the data obtained between 2005-2015, the researcher indicated that positive liquidity performance led to icreased performance of Albanian banks. Muriithi and Waweru, (2017) studied the effect of Liquidity Risk on Performance of Kenyan Banks by collecting data from the 43 registered banks in the country between 2005 and 2014. The liquidity coverage ratio (LCR) and net stable funding ratio (NSFR) were used to measure liquidity risk while bank performance was assessed using ROE. Random effects estimation and generalized method of moments (GMM) were used in the analysis of panel data. The overall effects of the analysis indicated that liquidity risk negatively affects performance meaning that it was necessary for the management to pay close attention to liquidity management.

\section{Conceptual Framework}

Independent Variable

Dependent Variable

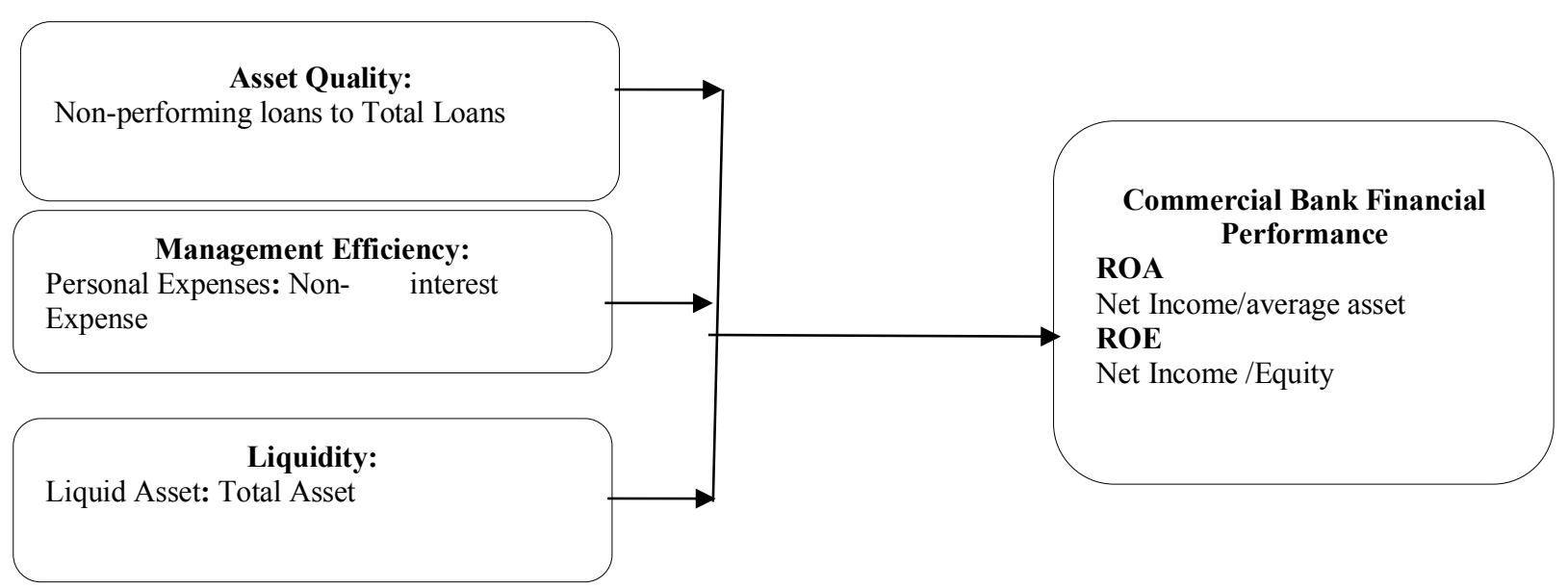

Figure 1: Research Model

Source: Authors

\section{Research and Methodology}

This research was grounded on positivism research philosophy. This kind of philosophy calls for the research problem to be structured around a methodology that enabled the research to generate quantifiable observations and undertake manipulation of the data by use of statistical methods. A descriptive survey research design was adopted for this study. Bryman and Bell (2007) affirm that descriptive cross-sectional design or social survey design allows for collection and examination of several aspects of the research question at the same. This allows the researcher to compare data between two or more variables thus determining how they associate and affect each other.

\section{Population and Sampling}

Target population refers to the elements of the population which the researcher requires to collect information concerning a particular subject (Baxter \& Jack, 2008). There are 29 indigenous and foreign banks operating in South Sudan. The study adopted a census sampling method since the target population is optimal. Hence the sample population for the study was 31 respondents. This enhanced the equal representation of the respondents and foster the response that was obtained from the study.

\section{Questionnaire Development}

Both primary and secondary data were used in the study. Primary data was collected through semi-structured questionnaires. Further the research constructed a key informant interview schedule that sought feedback from, bankers' association and Central Bank of South Sudan officials on the stability and performance of the commercial banks. Financial records of the banks from 2012-2017 were used as sources of secondary data.

\section{Analysis}

Quantitative data was analyzed using descriptive analysis and inferential analysis techniques with the help of Statistical Packages for Social Sciences (SPSS Version 23). Descriptive analysis included percentage, frequencies, means, standard deviations on the research variables. Inferential statistics will include multiple regression analysis and correlation to estimate the level of association between 
the research variables. The findings were presented using charts and tables as well as other infographics deemed appropriate such as the correlation matrix. The following model was adopted in the study;

$\mathbf{Y}=\alpha+\beta_{1} X_{1}+\beta_{2} X_{2}+\beta_{3} X_{3}+\varepsilon$

Where;

$\mathrm{Y}=$ Dependent variable (Financial Performance of Commercial banks in South Sudan - ROA, ROE)

$\alpha=$ the model intercept

$\beta_{1-5}=$ Coefficient of independent variables

$\mathbf{X}_{1}-$ Asset quality

$\mathbf{X}_{\mathbf{2}}$ - Management efficiency

$\mathbf{X}_{\mathbf{3}}$ - Liquidity

$\boldsymbol{\varepsilon}=$ Error Term

\section{Results and Discussion}

The current research sought to collect data from 24 commercial banks representatives within South Sudan. According to Figure 2 below, the rate of response was $92 \%(n=23)$.

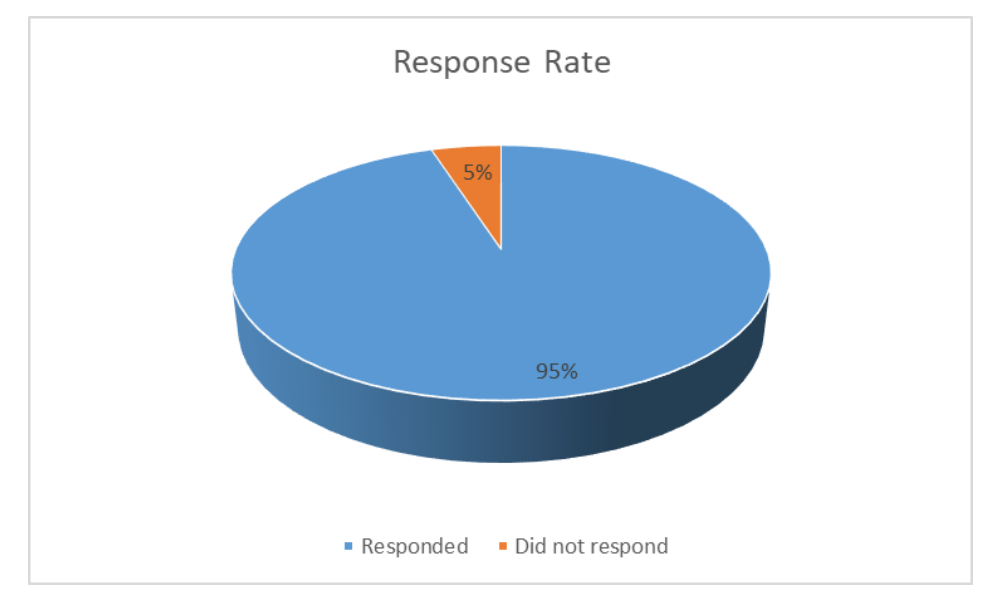

Figure 2: Response Rate

\section{Education of Respondents}

Table 1: Education of Respondents

\begin{tabular}{llll}
\hline & Frequency & Percent \\
\hline Doctorate & 1 & 4.3 \\
\cline { 2 - 4 } Masters & 7 & 30.4 \\
\cline { 2 - 3 } & Degree & 15 & 65.2 \\
\cline { 2 - 3 } & Total & 23 & 100.0 \\
\hline
\end{tabular}

According to table 1, 65\% $(n=15)$ of the respondents had attained degree level education, $30 \%(n=7)$ had a masters. The above findings indicate that there is growing professional competency within the personnel of South Sudan commercial banks which raises the employee technical capabilities.

\section{Descriptive Statistics}

\section{Influence of asset quality on financial performance}

Objective two sought to establish the influence of asset quality on the financial performance of South Sudan bank. 
Table 2: Asset quality and financial performance

\begin{tabular}{lcc}
\hline & N & Mean \\
\hline $\begin{array}{l}\text { Adequate possession of asset composition of commercial banks promotes } \\
\text { the performance of banks. }\end{array}$ & 23 & 4.1739 \\
\hline Holding high quality of assets increases bank's return & 23 & 3.9130 \\
\hline $\begin{array}{l}\text { Commercial banks in South Sudan use conservative provision of loan } \\
\text { losses }\end{array}$ & 23 & 3.9565 \\
\hline Loan portfolio quality contributes to positive bank performance & 23 & 4.07247 \\
\hline
\end{tabular}

\section{Source: Authors}

The results of the study on Table 3 indicated that with regard to adequate possession of asset composition of commercial banks promotes the performance of banks, a 4.1739 mean indicated strong agreement. The study findings further showed that regard holding high quality of assets increases bank's return, a 3.913 mean showed agreement while a .99604 deviation indicated moderate variation. Regarding commercial banks in South Sudan use conservative provision of loan losses, a 3.9565 indicated agreement. Concerning loan portfolio quality contributes to positive bank performance, a 4.2609 mean indicated strong agreement while a .61919 deviation indicated minimal dispersion.

\section{Influence of management efficiency on financial performance}

Objective three was to establish the influence of management efficiency on the financial performance of South Sudan banks.

Table 3: Management efficiency and financial performance

\begin{tabular}{|c|c|c|c|}
\hline & $\mathbf{N}$ & Mean & Std. Deviation \\
\hline $\begin{array}{l}\text { Efficiency within banks' management mitigates credit risk and fosters better returns } \\
\text { for the bank. }\end{array}$ & 23 & 4.2609 & .86431 \\
\hline $\begin{array}{l}\text { Efficient management enhances diversification of revenue stream for commercial } \\
\text { banks. }\end{array}$ & 23 & 4.3043 & .82212 \\
\hline Management efficiency leads to optimal operating expense within the firm. & 23 & 4.5652 & .58977 \\
\hline Efficiency in the management team promotes better investment ventures for the bank. & 23 & 4.3478 & .93462 \\
\hline Efficient management team ensures compliance to applicable laws and regulations & 23 & 4.3913 & .72232 \\
\hline
\end{tabular}

Source: Authors

The results of the study shown on Table 3 showed that regarding efficiency within banks' management mitigates credit risk and fosters better returns for the bank, a 4.2609 mean indicated strong agreement. Results indicated that respondents strongly agreed that efficient management enhances diversification of revenue stream as indicated by the 4.3043 mean with a .82212 deviation indicating moderate dispersion. The findings of the research further showed that with regard to management efficiency leads to optimal operating expense within the firm, a 4.5652 mean indicated strong agreement while a .58977 deviation denoted minimal variation. Regarding efficiency in the management team promotes better investment ventures for the bank, a 4.3478 mean indicated strong agreement. Concerning efficient management team ensures compliance to applicable laws and regulations, a 4.3913 mean indicated strong agreement.

\section{Influence of Liquidity on Financial Performance}

Objective five was to find out the influence of liquidity on the financial performance of South Sudan banks.

Table 4: Liquidity and financial performance

\begin{tabular}{lccc}
\hline & N & Mean & Std. Deviation \\
\hline $\begin{array}{l}\text { Adequate liquidity ensures bank is able to meet financial obligations in a timely } \\
\text { manner. }\end{array}$ & 23 & 4.0870 \\
\hline Access to optimal liquidity level ensures minimal loss in liquidation of assets & 23 & 4.16436 \\
\hline High liquidity levels lead to low profit levels within commercial banks & 23 & 3.8261 & .82212 \\
\hline
\end{tabular}

\section{Source: Authors}

The findings of the research showed that with regard to adequate liquidity ensures bank is able to meet financial obligations in a timely manner, a 4.087 mean indicated strong agreement. Regarding access to optimal liquidity level ensures minimal loss in 
liquidation of assets, a 4.3043 mean indicated strong agreement. Concerning high liquidity levels leads to low profit levels within commercial banks, a 3.8261 indicated agreement with a 1.07 deviation showing moderate dispersion.

\section{Inferential Analysis}

\section{Correlation Analysis}

\begin{tabular}{lll}
\hline & & Financial Performance \\
\hline Asset Quality & Pearson Correlation & .784 \\
\cline { 2 - 3 } & Sig. (2-tailed) & .001 \\
\cline { 2 - 3 } & $\mathrm{N}$ & 6 \\
\hline Management efficiency & Pearson Correlation & .758 \\
\cline { 2 - 3 } & Sig. (2-tailed) & .002 \\
\cline { 2 - 3 } & $\mathrm{N}$ & 6 \\
\hline Liquidity & Pearson Correlation & .620 \\
\cline { 2 - 3 } & Sig. (2-tailed) & .001 \\
\cline { 2 - 3 } & $\mathrm{N}$ & 6 \\
& & 6
\end{tabular}

\section{Source: Authors}

The results of the research indicated;

i. The association between asset quality and bank performance was positive and strong as attested by $\mathrm{p}$-value $=784$, Sig $=.001$.

ii. The relationship between management efficiency and bank performance was positive and strong as attested by $p$-value $=$ 758 , Sig $=.002$.

iii. The relationship between liquidity and bank performance was positive as attested by $p$-value $=620$, Sig $=.001$.

\section{Findings and Implications}

In regard to the asset quality, the findings made the researcher to differ with Acharya, et al., (2015) who indicated that increasing financial liabilities within emerging economies that were backed by poor asset quality in the financial industry did not result in better firm value. The researchers further did note that in Sub-Saharan Africa the lack of financial deepening in most of the countries contributed to poor bank performance since these banks mainly relied on lending as a revenue stream. These findings are in general supported by Ganguli, (2017) who posited that weak asset quality and lack of commercial banks diversifying their product portfolios led to their underperformance.

Concerning the management efficiency of commercial banks, the results of the study are not in congruence with Garang, Issa, and Ali (2017) who in their review of South Sudan transition to stability and fiscal sustainability indicated that poor capacity and lack of social and human capital were the major challenges to fiscal growth and performance of institutions. However, SirElkhatim and Salim (2015) are in support of the above findings; in their study on prediction of bank failures in Sudan between 2006-2014 they indicated that the quality of the management team of banks was key to fostering the banks financial growth.

Regarding liquidity, study findings are in are in line with Elgadi and Yu (2018) who examined returns of Sudanese banks indicated that the banks that were able to wither liquidity problems posted higher financial results than the other banks. These results are supported by Ndoka, Islami, and Shima, (2017) who concluded that there was a positive relation between liquidity and bank performance.

\section{Conclusions}

The study sought to examine the effect of bank stability on the financial performance of commercial banks in South Sudan. The study confirms the hypothesis that bank stability has a significant influence on the financial performance of commercial banks in South Sudan.

The research concludes banks perform better when they hold liquid assets since these increase their commercial income hence this should be encouraged. The quality of assets determines the credit risk. Higher credit risk reduces profitability; this can be avoided by adopting better screening policies that are geared towards an improvement of the service offering within the commercial banks. From the review of the results the study concludes that most of the commercial banks have enhanced their liquidity position over the 
past. The study further concludes that commercial banks should increase their holding of highly liquid assets as this will limit their default risk and increase their standing among lenders and other institutions.

The study is anticipated to enhance managerial practice and policy formulation within the banking industry. It is the recommendation of the study that at the bare minimum bank managers have to benchmark with industry experts on how to enhance their services and product offering to better their asset quality scores. Additionally, adequate research is necessary to determine the most suitable locations for bank branches to ensure that the banks maximize the return on investment. It is necessary for banks to position themselves such that they can meet their financial obligations at any time. It is necessary for the management to ensure that there is a balance between liquid and non-liquid assets.

The study suggests that further research work should be undertaken to examine how macroeconomic factors affect the performance of commercial banks in South Sudan owing to the continued volatility and instability in the country.

\section{References}

Acharya, V., Cecchetti, S. G., De Gregorio, J., Kalemli-Ozcan, S., Lane, P. R., \& Panizza, U. (2015). Corporate debt in emerging economies: A threat to financial stability? CigiOnline

Athanasoglou, P. P., Brissimis, S. N., \& Delis, M. D. (2008). Bank-specific, industry specific and macroeconomic determinants of bank profitability. Journal of International Financial Markets, Institutions and Money, 18(2), 121-136.

Bryman, A., \& Bell, E. (2007). Business Research Methods, (3rd ed.). New York: Oxford, University press.

Central banking News desk. (2012). South Sudan enacts central bank law', Retrieved from Central Banking: www.centralbanking.com/central-banking/news/2094427/south-sudan-enacts-central-bank-law

Chechet, I. L., \& A.B. Olayiwola. (2014). Capital Structure and Profitability of Nigerian Quoted Firms: The Agency Cost Theory Perspective. American International Journal of Social Sciences. 3 no.1,139-158.

Fang, Y., Hasan, I., \& Marton, K. (2014). Institutional development and bank stability: Evidence from transition countries. Journal of Banking \& Finance, 39, 160-176.

Ganguli, S. K. (2017). Asset Quality of Indian Banks-A Catch 22 Situation. ssrn papers, 1-16.

Garang, J. A., Issa, A., \& Ali, A. (2017). Assessing Transition to Stability, Fiscal Sustainability and Provision of Peace Dividend in South Sudan. Africa Portal.

Gatuhi, S. K. (2015). Macroeconomic factors and stock performance In Kenya.

Hansda, S. K. (1995). Performance variability of Public Sector Banks: Need for Strategic Planning. Reserve Bank of India occasional papers, 16(4), 313-341.

Hilscher, J., \& Raviv, A. (2014). Bank stability and market discipline: The effect of contingent capital on risk taking and default probability. Journal of Corporate Finance, 29, 542-560.

IMF. (2017). 2016 Article IV Consultation—Press Release: Staff Report; And Statement By The Executive Director For Sudan. International Monetary Fund.

Kadioglu, E., Telceken, N., \& Ocal, N. (2017). Effect of the Asset Quality on the Bank Profitability. International Journal of Economics and Finance, 9(7), 60.

Kotler, P., \& Armstrong, G. (2013). Principles of Marketing (14th ed). London: Pearson Prentice Hall.

Lamers, M., Mergaerts, F., Meuleman, E., \& Vander Vennet, R. (2016). The trade-off between monetary policy and bank stability. Retrieved from SSRN: https://papers.ssrn.com/sol3/papers.cfm?abstract_id=2896747

Naceur, S., \& Omran, M. (2010). The effects of bank regulations, competition and financial reforms on banks` performance. Emerging markets review, doi: 10.1016 .

Ndoka, S., Islami, M., \& Shima, J. (2017). The impact of liquidity risk management on the performance of Albanian Commercial Banks during the period 2005-2015. International Journal of Social Sciences and Education Research, 3(1), 70-76.

Ongore, V. O., \& Kusa, G. B. (2013). Determinants of financial performance of commercial banks in Kenya. International Journal of Economics and Financial Issues, 3 (1), 237-252.

Pearce, J. A., \& Robinson, R. B. (2011). Strategic Management: Strategy Formulation, Implementation, and Control (12th ed). Chicago, IL: R. D.: Irwin, Inc.

Sarker, M. N., Sultana, A., \& Prodhan, A. S. (2017). Financial Performance Analysis of Islamic Bank in Bangladesh: A Case Study on Al-Arafah Islami Bank Limited. World, 3(1), 052-060.

SirElkhatim, M. A., \& Salim, N. (. (2015). Predicting Bank Financial Failures Using Discriminant Analysis, And Support Vector Machines Methods: A Comparative Analysis in Commercial Banks in Sudan (2006-2014). International Journal of Scientific \& Technology Research 4, no. 8 (2015): 207-214. 